\title{
Giving Miss Marple a \\ Makeover: Graduate \\ Recruitment, Systems \\ Failure, and the Scottish \\ Voluntary Sector
}

\author{
Scott. A. Hurrell,' Chris Warhurst, ${ }^{2}$ and \\ Dennis Nickson ${ }^{2}$
}

\begin{abstract}
The voluntary sector in Scotland, as across the globe, is becoming increasingly business like. Resultantly, there is an increasing demand for graduates to work in business and support functions. In Scotland, however, despite an oversupply of graduates in the labor market, the voluntary sector reports skills shortages for graduate-level positions; a leadership deficit was also reported in countries such as the United States. Through exploratory, mainly qualitative, case study and stakeholder research, this article proposes that one reason for this mismatch between the supply of and demand for graduates is a systems failure within the sector. Many graduates and university students remain unaware of potentially suitable paid job opportunities, in part because of the sector's voluntary label. To rectify this systems failure, thought needs to be given to the sector's nomenclature and the manner in which voluntary sector organizations attract graduate recruits, for example, through levering value congruence in potential recruits.
\end{abstract}


In Scotland, as with the rest of the United Kingdom and many other advanced economies, the state is being hollowed out as public services are contracted out to the voluntary sector. As part of this process, voluntary organizations are being required to provide better services. This better service provision in turn requires employees with better skills, particularly graduates, as voluntary organizations seek to become more business like. However, despite an expanding supply of graduates in the labor market and evidence that this supply outstrips demand in the economy as a whole, insufficient numbers of graduates are being attracted to the voluntary sector. As a consequence, the sector has skill shortages now and a potential future leadership deficit that need to be addressed.

The key question then is why, when graduates are plentiful, is an insufficient number being attracted to a sector that needs them. This article examines this question. It argues that the cause lies with a systems failure, leading to a mismatch between the demand for and supply of graduates in the voluntary sector. In its analysis of this failure, the article draws on exploratory empirical research conducted in the social care subsector of the Scottish voluntary sector. Given the needs of the sector, the research focuses on graduates possessing university degrees in subjects such as business rather than those graduates with degrees such as social work that are traditionally regarded as relevant to the social care sector. The empirical data is mainly qualitative, drawn from interviews and focus groups, though is supplemented by quantitative survey data.

The article begins by outlining current developments in the voluntary sector and graduate labor market and suggests that a systems failure might explain the mismatch between the high demand for but poor supply of graduates to the voluntary sector. Following a short outline of the research project and methods, the hypothesized systems failure is tested through the empirical research. The research findings focus on voluntary sector-employer demand for graduates, misperceptions held by graduates about the sector, and the attractiveness of the sector to graduates. Although recognizing a number of barriers, the article concludes by discussing how the systems failure and so problems in attracting graduates to the voluntary sector might be addressed.

\section{Voluntary Sector Jobs, Graduate Labor, and Systems Failure}

Over the past 20 years in the United Kingdom, social services have been contracted out by central and local government. Their transfer from the public to the voluntary sector is seen as "a more palatable alternative to outright privatization" (Labour Research, 2007a, p. 14; see also Labour Research, 2007b). Consequently, funding of the voluntary sector by both central and local government has increased significantly over recent years. In 2002, $47 \%$ of the sector's income came from government contracts - in 2006, 62\% (Little, 2008). Indeed, 2005-2006 was a watershed, from which point most voluntary organizations' income became earned rather than a result of donations (Brindle, 2008). Nonetheless, income from government is constrained, 
with only one in eight voluntary organizations receiving full cost recovery from government for the provision of transferred services (Labour Research, 2007a). As the state is hollowed out and services transferred, there is pressure from the government for voluntary organizations to improve service delivery through more cost effectiveness and, at the same time, to have better qualified staff to deliver these services (Meyer, 2006). Thus, as public services are outsourced to the sector, voluntary organizations are being required to professionalize their organization and management to become more business like (Dart, 2004; Parry, Kelliher, Mills, \& Tyson, 2005; Wilson \& Larson, 2002).

Despite the voluntary label, it is paid staff who are the key workforce within the voluntary sector. Already in Scotland the sector is a significant employer, with voluntary sector jobs comprising about $5 \%$ of the country's total workforce (Wilding, Collins, Jochum, \& Wainwright, 2004). Moreover, job growth has been strong with a 17\% increase between 1997 and 2001 (Shah, 2004). At the same time, voluntary organizations report recruitment difficulties. The 2004 Scottish Employers Skills Survey reports skills shortages (as defined by the existence of hard-to-fill vacancies) by $9 \%$ of voluntary organizations compared to $5 \%$ of organizations in the public and private sectors (Futureskills Scotland, 2005). Future recruitment difficulties are also anticipated by more than $25 \%$ of voluntary organizations, according to Munro and Shah (2004).

As a consequence of these recruitment problems, skills gaps are emerging in the sector, particularly for "highly skilled leaders" (ATA Management, 2006, p. 12) and, as in the United States (Tierney, 2006), a potential, future leadership deficit is a concern. Wilding, Collis, Lacey, and McCullough (2003) have concluded therefore that the priority skill needs for voluntary organizations centre on leadership and management skills, including planning and organizing, project management, strategic planning, partnership working, and fundraising skills.

Such skills are developed at university (Mason, 2001) and so, not surprisingly, the demand for graduates is rising. Unfortunately, although voluntary organizations need more graduates, they are failing to attract them. As a consequence, the recruitment of graduates is now a key concern for the sector (Munro \& Shah, 2004).

Within the United States, it has been noted that demographics underpin the nonprofit leadership deficit as baby-boom executives retire (Tierney, 2006). This deficit requires, among other measures, the exploration of new talent pools by nonprofit organizations, including "young managers in training" on suitable university courses (Tierney, 2006, p. 24). Indeed, within the United Kingdom, graduate labor is plentiful, highlighting a similarly untapped pool of talent. Business-related and social science degrees are now among the most popular subjects studied in United Kingdom and Scottish higher education (Bates, Tyers, Connor, \& Loukas, 2006; Higher Education Statistics Authority, 2008a). The U.K. government has intentionally expanded higher education to increase the supply of graduates in the labor market. However, the supply of graduates within the labor market now outstrips demand, so there are difficulties for graduates to find graduate jobs. Recent 
U.K.-wide figures suggest that the supply of workers with degrees outstrips employer demand for them by approximately 1.1 million (Felstead, Gallie, Green, $\&$ Zhou, 2007). Brown and Hesketh (2004) claimed that there are now between 7 and 20 graduates for every graduate job. The U.K. Graduate First Destinations surveys for 2001 and 2002 show that $20 \%$ and $22 \%$ of respondents respectively were in nongraduate jobs (Perryman, 2002, 2003). In Scotland, one survey showed that approximately $61 \%$ of Scottish graduates were initially in jobs both requiring a degree and utilizing their graduate skills compared to $52 \%$ across the United Kingdom as a whole (Elias \& Purcell, 2001). Among the 25 to 34 age group, however, the relative advantage enjoyed by Scottish graduates disappears, with $18 \%$ of Scottish graduates in nongraduate jobs compared to $15 \%$ across the United Kingdom (Bates et al., 2006). For those not in graduate jobs, underemployment is a problem, with many not able to utilize their graduate skills, as suggested by Brown and Hesketh (2004). Scottish employers are particularly poor at growing jobs to utilize graduate skills. Only $11 \%$ of graduates in Scotland working in nongraduate jobs reported that their jobs had been grown to utilize their skills compared to $17 \%$ for the United Kingdom (Elias \& Purcell, 2001). Moreover, Scottish graduate unemployment is worse than for the United Kingdom, with graduates in Scotland more likely to be unemployed 18 months to 3 years after graduation (Bates et al., 2006; Elias \& Purcell, 2001). At 6\%, the unemployment rate among business and social science graduates is among the highest of all degree subjects in the United Kingdom (Higher Education Statistics Authority, 2008b), even if slightly lower at 4\% for Scotland (Scottish Government, 2008). Nevertheless, there is evidence that Scotland is a net exporter of graduates and experiences a brain drain. Almost 19\% of Scottish graduates find employment elsewhere in the United Kingdom compared to only $1 \%$ who study elsewhere in the United Kingdom and subsequently work in Scotland (Bates \& Tyers, 2006). Such data indicate that there is a significant minority of graduates, generally and in business and social science specifically, who could conceivably find employment in a professionalizing voluntary sector.

Pay is often cited as a source of recruitment problems for the voluntary sector (Nickson, Warhurst, Dutton, \& Hurrell, 2008). Certainly, pay in the U.K. voluntary sector tends to be lower than in the private and public sectors. Managers (jobs for which graduates might be suited) in the U.K. public sector, for example, earn considerably more than those in the voluntary sector. In Parry et al.'s (2005) study of London-based drug and alcohol services, the average wage for managers in the voluntary sector was $£ 27,531$ compared to $£ 35,706$ in the public sector. In Scotland, voluntary sector pay is lower than in England and Wales and has dropped by $2 \%$ comparatively. This difference translates to an average weekly pay differential of $13 \%$ with the private sector and $20 \%$ with the public sector (Barnard, Broach, \& Wakefield, 2004; Shah, 2004).

However, research on the voluntary sector indicates that although lower pay might not be desirable, it is not axiomatically a deterrent to higher skilled workers. There appears to be an altruism payoff in which employees, including those in management, 
are willing to trade off lower salaries against task significance, recognizing that work in the sector has a high social importance (Nickson et al., 2008; Parsons \& Broadbridge, 2006; Wilson \& Larson, 2002). This identification of an altruism payoff reflects research conducted on public service motivation (PSM). Having PSM results in public sector employees, again including those in management, placing greater value on service and intrinsic rather than extrinsic work rewards (Perry, Brudney, Coursey, \& Littlepage, 2008). Similarly, the focus on task significance within the voluntary sector has been labeled as a voluntary sector ethos, with employees in the sector displaying a high affective commitment to their organizations (Cunningham, 2005 and Meyer \& Allen, 1991, respectively). This point is significant; graduates orientated to the sector tend to be more interested in "making a difference rather than making a fortune," according to the director of nonprofit sector recruitment firm Accenture Development Partnership (quoted in Murray, 2008, p. 6).

Consequently, there is opportunity for levering value congruence between some graduates and the voluntary sector. The possibility of doing so is revealed in Brown and Hesketh's (2004) study of the values that are important in shaping the job choices of graduates. This research identified two extreme types of behavior in graduates applying for jobs. These types are labeled players and purists. Players, as the name suggests, "play the game" and use information gathered from companies beforehand to "market [themselves] in ways that conformed to the broader requirements of employers" (Brown \& Hesketh, 2004, p. 127). They are competitive, self-promotional, and "fake it" to get jobs. By contrast, purists carefully research organizations to match their values with those of potential employers, applying for those organizations which fit their "authentic selves" and remaining true to their personal values (Brown \& Hesketh, 2004, p. 142). Purist graduates could, therefore, be attracted to the voluntary sector through better information provision on both the availability of graduate job opportunities and organizations' values.

In this respect, the reason that too few graduates are being attracted to the sector might be because of a systems failure. A market failure occurs when there are too few workers in the labor market with the appropriate skills because, for example, there is an absence of trained workers as no training provider exists or as employers are unwilling to train staff (Keep \& Mayhew, 1999). In both cases, the outcome is a mismatch between supply and demand created by a quantitative shortfall in the stock of skills in the labor market. With an oversupply of graduates, market failure cannot explain graduate recruitment problems.

The explanation for these problems might rest instead with a systems failure. With a systems failure, there is an apposite number of appropriately skilled workers in the labor market, but these workers are not properly matched to the employers who need them, with employers thus failing to maintain equilibrium between supply and demand. As such, the cause of systems failure relates more to the efficacy of institutions (or procedures) than the operation of the market. Keep and Mayhew (1999) discussed this occurrence in relation to product strategies that demand and use low skills and thus keep the United Kingdom in a low-skills equilibrium, but the concept can 
usefully be applied to employer strategies in other areas, such as recruitment, where the systems used to attract graduates to the voluntary sector are failing to take advantage of the available supply.

Framed as a systems failure, the sector's graduate recruitment problems can be analyzed through the attraction selection attrition (ASA) framework developed by Schneider, Goldstein, and Smith (1995). This ASA framework posits that people are attracted to organizations that share the same values as themselves and stay with these organizations if value congruence is maintained. This focus on attracting individuals with commensurate values has implications for voluntary organizations in attempting to attract labor. Applicants become the focus of the selection process as they have a large degree of agency in choosing for whom to work, and attraction to organizations becomes a two-way social process in which the applicant selects the organization as much as the organization selects the applicant (Herriot, 1989). By providing appropriate information about the job and organization during recruitment, selection voluntary sector organizations may be able to attract graduates whose values are commensurate with their own.

That such a systems failure might be occurring is beginning to gain purchase in the United Kingdom. A report of U.K.-wide research commissioned specifically to address the problem of attracting graduates into the voluntary sector states that "Although there is a need to attract high-caliber new talent, there appears to be a lack of awareness among graduates and school leavers about the range and scope of career opportunities within the sector" (ATA Management, 2006, p. 5). Other research reveals that knowledge of the sector among young people (and so potential future employees, graduates, and otherwise) is poor. A survey of 50013 - to 19-year-olds found that $31 \%$ knew nothing of the sector, whereas a further $54 \%$ knew only "a little." Further qualitative research highlighted that most of the young people interviewed associated the sector with volunteering. When asked to name jobs in the voluntary sector, most respondents could only cite charity shop work and believed that no qualifications were required to work in the sector. The image of the sector was also poor - regarded as out of touch and populated by old, retired, kind-hearted women. When asked to select an image that typified the type of person working in the sector, the majority selected an image of Agatha Christie's Miss Marple, the quintessentially English grandmother figure (Zebra Square, 2006). Such attitudes, held at the point of leaving school, are unlikely to change over the course of young people's university study unless they are explicitly informed otherwise. This lack of awareness about the job possibilities within the sector suggests that the voluntary sector is not good at communicating information about itself to potential applicants.

From these studies, it might be hypothesized that a systems failure exists that is creating graduate recruitment problems for the voluntary sector in Scotland. Needing to professionalize its management and organization, and avoid a leadership deficit, this sector needs graduates and their skills. There is, concurrently, an oversupply of graduates in the Scottish labor market who are both underemployed and, in some cases, unemployed but who are not entering the sector. The reason appears to be that 
graduates are insufficiently aware of the job opportunities offered by the sector. As a consequence, although there are graduates available, they are not being attracted to the sector. Supply and demand therefore, although notionally commensurate, are not being matched. This article tests the systems-failure hypothesis by drawing on empirical research undertaken in the social care subsector. Three particular issues are examined, which together would indicate a systems failure of this type: First, whether a demand for graduates exists in the social care subsector; second, whether graduates have misperceptions about the voluntary sector and work within it; finally, whether voluntary sector organizations are an attractive employment option for graduates. This approach thus covers demand- and supply-side issues and whether it is possible for these to be reconciled.

\section{An Outline of the Research}

The social care subsector is the largest single employer in the sector in both the United Kingdom and Scotland (Barnard et al., 2004; Shah, 2004). The research was stimulated by an exploration of recruitment difficulties in the voluntary sector commissioned by a human resource directors' network of a number voluntary sector organizations in the social care subsector (see Nickson et al., 2008). The research encompassed seven leading Scottish-based voluntary sector organizations from the social care subsector (anonymized as Supportco, Stratos, Houseco, Liveco, Nimbus, Diversico, and Kidco). The organizations provided a range of services for disadvantaged groups, including the physically and mentally impaired, single parent families, and vulnerable children. Each organization had between 180 and 1,400 employees. The research methods included a structured telephone survey that covered issues related to recruitment, pay, and person-organization fit as well as perceptions and expectation of work in the sector. Respondents were identified by the organizations, stratified in terms of managers/front-line workers, and the size of the organization. An intentional sample of 100 front-line, nonmanagerial staff and 30 managers across the seven organizations was interviewed. In-depth, face-to-face interviews were also conducted with the human resource director from each of the seven organizations plus a human resources assistant from Kidco who accompanied her director. Interview topics covered the activities and characteristics of the organizations and sector, any changes affecting the organizations, the existence of and reasons for any recruitment problems, and why workers might wish to work in the sector. This first stage of the research identified problems in graduate recruitment but was concerned with recruitment in general, with the telephone survey focusing on front-line caring roles.

To explore the graduate recruitment problems further, the fieldwork was extended to consider other stakeholders. The director of a pilot graduate placement scheme run by a Scottish organizing body for voluntary organizations (Umbrellaorg) was interviewed. This pilot scheme placed six new graduates on projects within voluntary sector organizations where a demand for graduate abilities was unfulfilled. Interviews 
with representatives from three employers attending a conference designed to attract graduates to the sector were also conducted. One of these respondents was from Stratos, from the initial research, whereas the other two representatives were from Schoolco, an educational service provider, and Eastnet, a regional organizing network. Eastnet had also been part of the pilot placement scheme. The interviews for this second stage were semistructured and designed to allow respondents to explore their experiences of the demand for, and recruitment of, graduates. As part of the initial research, interviews with university careers advisers and students were also included. Five careers advisers from three (again anonymized) Scottish universities (Westuni, Eastuni, and Northuni) were interviewed, three in Westuni and one each from the other institutions. Two focus groups were conducted, one with final-year arts business and social science students from Westuni and one with recently graduated social workers, from the same university. The interviews and focus groups included questions on students' and graduates' perceptions of the voluntary sector, whether the sector is a potentially attractive destination for graduates and the extent to which voluntary sector organizations market themselves as graduate employers.

The research findings are now structured around the three issues, identified above, on which the research focused: the demand for graduates within the sample, the perceptions graduates had of the sector, and the attractiveness of the voluntary sector as a graduate employer.

\section{Research Findings}

\section{Professionalization and the Demand for Graduates in the Voluntary Sector}

All the human resource directors and the director of the pilot graduate placement scheme emphasized that the sector was undergoing wholesale change in terms of its professionalization, particularly in terms of business support functions within organizations. Indicatively, the human resource directors had all faced increased pressures to develop their organization's human resource function to align it with that in the public and private sectors. All seven of the organizations stated how their human resource departments were growing and becoming more business like. This trend was epitomized by the human resource manager of Stratos, who stated that work in the sector was "not just tea and sympathy ... you're running a project ... [people think the sector is] cardigans_-soft and woolly_-but that's not what it's like, it's actually a lot more business focused."

Unsurprisingly, given the focus of the initial research, recruitment and selection were the most commonly mentioned professionalization developments. Five organizations (Supportco, Stratos, Nimbus, Houseco, and Diversico) were standardizing recruitment advertising and developing new recruitment and selection policies and practices. Liveco was preoccupied with training, especially in relation to devolving human resource management to line managers. All were looking to develop human resource policies to create consistency throughout the organization in an effort to 
improve business performance. The Houseco respondent typified the prevailing feeling that previously "things were just a bit higgledy piggledy, all over the place."

In all organizations, the human resource function had originally been the responsibility of a sole person or delegated to undifferentiated administration staff; now each organization's human resource department is expanding. In Kidco, prior to the human resource manager's arrival there had been no training for staff dealing with human resource issues. Now, Kidco had two and half professional posts (at a graduate level) and two human resource administrator posts. Similarly, Supportco and Nimbus had a growing human resource staff and were developing further professional posts. The human resource director in Stratos had managed to "source" a graduate to help her develop and implement a staff appraisal system. Despite the growth of business functions, some of the human resource directors wanted further help, with the directors of Stratos and Nimbus wanting to employ more graduates in their human resource departments. The Diversico representative, for example, believed that their human resource department was "reasonably sized [but] not big enough for the organization."

Growth of other business-support functions was also evident, and a similar demand for graduates existed. Houseco had experienced information and communication technology (ICT) problems and believed that the organization's ICT infrastructure needed further development, offering a job opportunity for a graduate. Within Nimbus, the public relations/marketing function had been developed with the recent appointment of a director of communications, and the intention was to expand the department further. Similarly, Liveco had a well-developed business service division, including marketing, finance, administration, and training. Kidco also had an IT specialist and a media/marketing department as well as growing human resources and administration functions. The human resource directors of Stratos and Schoolco, attending the graduate careers conference, stated that the demand for graduates was primarily in support functions, such as administration, finance, ICT, public relations/ media, marketing, and human resources. The growth of these business functions was attributed to the fact that the organizations' service provision was expanding rapidly. Indeed, the graduate placement offered by Eastnet was in explicit response to a need within the organization for someone with marketing expertise. As part of this project, the graduate intern developed a market research questionnaire using the expertise developed on her degree, her presence meaning that "we [Eastnet] had an expert there on hand."

It was because of this expansion in business functions that Umbrellaorg's pilot graduate placement scheme had been developed. The director of the scheme stated that the placements overwhelmingly demanded "either graduates . . . to develop a marketing strategy or IT" and, he continued, "showed us there was a skills shortage there." This skills shortage was attributed to the fact that organizations were becoming less of an "Aunt Sally"1 and more professional in operation. As a consequence, the requests from organizations for graduate placements were greater than the number of graduates for which the scheme had funding available to place but 
demonstrated, the director claimed, the demand for graduates from the sector. The respondents thus strongly supported the need for the sector to be more business-like with more graduate employees, as identified, for example, by Dart (2004) and Munro and Shah (2004), respectively.

\section{Misperceptions of the Voluntary Sector}

Graduate opportunities clearly existed in Scottish voluntary organizations. The issue then becomes whether graduates are aware of these opportunities and whether a systems failure exists. Indication of that failure came immediately in the purpose of Umbrellaorg's graduate placement scheme, which had been developed partly because many graduates had little or no idea about jobs in the voluntary sector. The director of the scheme explained that

we very often are surprised ourselves at the surprise on graduates' faces [when they] learn that there are actually jobs in the voluntary sector ... the assumptions seem to be that the voluntary sector is about volunteering and about do[ing] good works.

This misperception was also apparent in the focus group of final-year students at Westuni. There was general confusion about what the sector offered. One participant believed that the sector was about "working in like charity shops, befriending in the community, community kind of work, that kind of stuff." This comment prompted another student to agree that the sector did not offer paid opportunities but instead was about "working out the goodness of your heart as opposed for cash"- a view which was typical for the group. The majority of the students had little idea that paid jobs existed in the voluntary sector, let alone that such jobs might be suitable for graduates. All of the respondents had applied to the typical large private sector companies offering fast-track placements and had not even considered the voluntary sector. When presented with information about job possibilities within the voluntary sector, they were genuinely interested, especially in marketing/media positions and project management.

Although the focus of this article is graduates with degrees unrelated to social care, a further focus group conducted with social work graduates also revealed perceptual problems with the sector. These graduates typically find work in the public sector, and all the focus-group participants assumed that it would be in this sector that they would find employment. Two of the participants, however, had recently worked in voluntary sector organizations as work placements as part of their course. They admitted that they had been surprised by the job opportunities within the voluntary sector and as one stated, "it wasn't until I actually worked in a voluntary organization [on a placement] that I actually realized the value of it so I think it's a lack of information." The respondents realized that their initial misperceptions were also common among the 
general public. One of the two students had encountered public unawareness when attending a focus group held by a Scottish national newspaper:

This woman was sitting there and slagging off the voluntary sector and she said well they're just a bunch of middle-class do-gooders, and I said, "Excuse me but they actually employ professional qualified people ... we're not sitting knitting tea cosies and selling them" and I was raging at her.

This misperception problem was acknowledged by the human resource directors from the seven organizations of the initial research, who admitted that most people still perceived the sector as amateurish. This misperception affects the sector's perceived attractiveness as a potential employer for those graduates who have no direct experience of voluntary organizations.

The careers advisers also acknowledged the misperception problem for the sector. Westuni did inform students of the voluntary sector as a career option, although this possibility often needed careful explanation to students as "you have to make them aware that you are talking paid jobs because the tendency is for them to think 'Well that would be nice but I can't afford to work for nothing." However, as one careers adviser stated, "Once they [students] start to look, they're quite amazed by the breadth of the types of organizations and the types of jobs."

Clearly, the voluntary sector suffers from misperceptions, particularly in relation to employment opportunities, with students and recent graduates largely unaware of the existence of paid graduate job opportunities. The various respondents believed that poor communication and information exchange was apparent between the sector on one side and universities and individuals on the other side. This problem was regarded as a key contributor to the misperceptions among graduates (and the public as a whole) about the nature of work within the voluntary sector organizations and job opportunities.

The director of the placement scheme was aware that the misperceptions held by graduates arose because of the lack of direction from careers advisers, who acted as labor market gatekeepers, but acknowledged that responsibility for it also lay with the voluntary sector and its organizations. He stated,

We stand condemned as well ... We have never really approached the academic world and careers advisers in any meaningful way ... We have failed miserably to promote the voluntary sector as a [graduate] career opportunity in the past.

The graduate placement scheme had highlighted to Umbrellaorg that the sector needed to act differently if it was to promote itself as a graduate career opportunity. This view was shared by both the careers advisers and students. The careers adviser from Northuni stated, 
I think they [the voluntary sector] need to market themselves as graduate employers if they want to target students. I'm not aware that they do that or voluntary sector organizations have graduate training schemes. Other employers come and do presentations at the university to talk about the work they do.

Furthermore, the same respondent stated that where voluntary organizations did market themselves at careers fairs they were often promoting volunteering. As such, it is understandable that potential graduate employees have misperceptions about employment opportunities within the sector. The careers advisers at Westuni had no formal links with any voluntary sector organizations and believed that the sector was not proactive in promoting itself as a graduate employer. According to the careers advisers, the voluntary sector could do much more in terms of attracting graduates. The students at Westuni shared this sentiment and believed that if the voluntary sector was more visible on campus this presence would help to change the perceptions of students about the sector and associated graduate job opportunities within organizations. As one focus-group student stated bluntly, "It would diminish the myth if they actually came out to the universities and said this is what we have to offer." The respondents thus recognized a systems failure (Keep \& Mayhew, 1999 ) in the voluntary sector's attempts to attract graduates, with inappropriate recruitment processes in operation. This failure appeared to inhibit the attraction of graduates, despite the demand for them from the sector and graduates' plentiful supply in the labor market.

\section{Attracting Graduates to the Voluntary Sector}

Despite this demand, another key issue is whether the voluntary sector is an attractive option for graduates. Perhaps, the biggest potential problem in this respect, as noted earlier, is poor pay. This problem was affirmed by the human resource directors in the initial research, although predominantly in relation to front-line care rather than graduate jobs (see Nickson et al., 2008). The funding problems caused by full cost recovery noted previously were seen as a major reason why pay rates were not competitive. Full cost recovery typically involves the funder, which is usually the local government, providing for the costs of direct service delivery and not contextual costs, such as those linked to training, career development for staff, or organizations' ability to pay market-competitive salaries, for example. The human resource director of Liveco typified this problem, saying, "We put our salaries up a thousand [pounds], but we still can't enter into the high-wage bracket because we're restricted to the money that the social work department [of the local government] will give us to meet this package."

A further concern was the perception that career development in the sector was poor. Indeed, none of the graduates placed in voluntary sector pilot placement scheme subsequently secured permanent employment within those organizations because of the funding issues. 
Notwithstanding these problems about pay and the permanency of graduate positions, the voluntary sector potentially offers job prospects that would be attractive to graduate recruits. The human resource directors attending the careers conference believed that the relatively informal and flat structures of many voluntary organizations actually offered graduates more opportunity to use their skills than might be the case in private or public sector organizations. The human resource director from Stratos, for example, believed that it was possible for graduates to grow their jobs:

The voluntary sector offers a range of opportunities that aren't necessarily available in the public or private sector because the same things that are challenges for us, particularly the fact that we are tightly resourced and money is scarce, means that often when somebody comes in to do a particular job, they often have the opportunity to get involved in other areas of the business.

The human resource director from Schoolco believed that those graduates with particular expertise would be "listened to" in voluntary sector organizations to a greater extent than in the private sector. The skills necessary for working independently and showing initiative, typically associated with graduates, could clearly be mobilized in such situations. Linked to the tight resourcing of voluntary sector organizations, graduates could gain considerable responsibility at an early stage in their career as "you might well be the 'team' in a voluntary organization, which is a huge opportunity," Schoolco's human resources director stated. The opportunity to grow jobs in the sector was also signaled by this director. He stated that many people applying for administration posts were graduates and that Schoolco tended to "grow a lot of functions out of people [graduates] who joined us as admin staff."

Resonating with the Schoolco director's comments, the human resource directors of Supportco, Nimbus, and Kidco had themselves developed their organizations' human resource function. Clearly, the opportunities exist for graduates to take ownership of projects relatively early within organizations and use their skills. The fact that graduates entering nongraduate jobs in other sectors such as retail subsequently cannot grow their jobs in this way (Mason, 2001) suggests a way in which the voluntary sector can market itself to potential graduate recruits.

Significantly, even where permanent graduate positions were not available because of funding, short-term job opportunities with voluntary organizations still enabled graduates to utilize their skills. Furthermore, such opportunities could then lever other jobs elsewhere in the voluntary sector or in other sectors. This point was emphasized by the director of the graduate placement scheme. Such placements, he said, were preferable to graduates over shelf-stacking jobs in supermarkets because of the opportunities in the former to use their skills and develop their employability. One graduate placed with Eastnet attributed her success in securing a subsequent job in the private sector to experiences gained from her voluntary sector work placement. Other graduates remained within the sector despite not securing permanent employment within their original placement organization. The director stated that at least 
two of the six graduates had completed additional project work for the placement provider, whereas others had completed short-term projects for other voluntary organizations. Indeed, the Eastnet representative stated that another graduate trainee employed directly by the organization had used her experiences to then progress to work for one of Scotland's largest and best-known voluntary sector organizations. Although it is not possible to generalize from the pilot graduate placement scheme, the opportunity for some graduates to undertake project work within the voluntary sector can clearly offer opportunities for graduates to develop their employability and then springboard to jobs in other voluntary organizations or other sectors. The opportunity for graduates to use their skills in the voluntary sector could, therefore, be a significant pull factor for graduates, especially given the significant minority of graduates in Scotland and the United Kingdom as a whole who are not using their graduate skills at work (Bates et al., 2006; Felstead et al., 2007).

In addition, as discussed above, the attractiveness of the sector may be improved by levering value congruence between employing organizations and potential graduate employees, creating fit between the potential graduate applicants' values and those of the organization. Resonating with Schneider et al.'s (1995) ASA framework, voluntary organizations can attract labor through the promotion of their values as much as through the advertising of pay rates. This possibility is revealed in the reasons given by employees for joining voluntary organizations. Table 1 reports findings from the telephone survey and reveals the mean importance attributed to various reasons for joining the organization. The table shows that the top four reasons for joining the organization were not related to extrinsic factors such as pay but rather intrinsic factors such as the nature of the work and the values of the organization.

Although it must be noted that the majority of these respondents were front-line care employees, the results support the assertion of an affective commitment in the voluntary sector or a voluntary sector ethos. The overwhelming finding from the recruitment survey for both front-line employees and managers in social care was that workers joined the voluntary sector because it was "something to believe in" (Nickson et al., 2008). Interviewees were often attracted by the fact that their organizations' values were consistent with their own rather than because of pay or working conditions. This affective commitment was confirmed by the human resource directors in relation to both their staff and themselves. The human resource assistant in Kidco believed that her job was the "ideal opportunity" for her in terms of her values as she had "always wanted to work in the voluntary sector." The human resource directors of Supportco, Nimbus, and Houseco also expressed contentment with working in the sector after becoming disillusioned with work in the public or private sectors. Supportco's human resources director would now not consider returning to the private sector: "[Supportco is] something I can actually be passionate about. It's quite hard to get worked up about bits of software or whatever." Significantly, the human resource directors also noted that value congruence could help attract graduates to the sector. For example, Nimbus had recently taken on a couple of graduates who had "liked the idea of the sector." By focusing on the values of the organization in 
Table I. Importance of Reasons for Joining the Voluntary Organization

\begin{tabular}{lcc}
\hline Reason & Mean score $^{\mathrm{a}}$ & Standard deviation \\
\hline Type of work & 2.69 & 0.49 \\
Nature of caring work & 2.62 & 0.56 \\
Values of the organization & 2.51 & 0.60 \\
What the organization stands for & 2.51 & 0.63 \\
Working conditions & 2.15 & 0.67 \\
Working hours & 2.03 & 0.78 \\
Other people in organization & 1.81 & 0.78 \\
Pay & 1.76 & 0.62 \\
Childcare (of own children) & 1.55 & 0.83 \\
Partner's job & 1.31 & 0.62 \\
Lack of alternative work & 1.16 & 0.45 \\
Any other reason & 1.06 & 0.23 \\
\hline
\end{tabular}

Note: $N=1 \mid 4$.

a.A 3-point scale was used with the end points being not important (I) and very important (3).

recruitment and providing information about those values to applicants in a two-way social selection process (Herriot, 1989), voluntary sector organizations may be able to attract and secure those who have commensurate values. Specifically, in relation to the attraction of graduates, voluntary sector organizations can use value-based recruitment to secure the services of purist graduates who remain true to their own values and choose to work for organizations whose values fit their own (Brown \& Hesketh, 2004).

\section{Discussion and Conclusion}

The voluntary sector is becoming an increasingly important employer and is also facing increasing requirements to be more business-like. In turn, this shift is triggering new skill requirements of voluntary organizations for which they currently have shortages, particularly in relation to business functions. Graduates are deemed to possess these skills, and the research presented affirms a demand by voluntary sector employers for graduates. However, despite the expanding number of graduates in the labor market - with many graduates unemployed or underemployed and not using their skills - the voluntary sector has difficulties attracting graduate labor. This article hypothesized that these difficulties stem from a systems failure with a mismatch between the demand for and supply of graduates in the voluntary sector. The findings support this hypothesis, revealing that although graduate supply is plentiful and many voluntary sector organizations increasingly demand graduate labor, a mismatch of supply and demand is occurring. This mismatch is occurring because of misperceptions about the sector among potential graduate recruits due to voluntary organizations' failure to adequately communicate information about the sector to graduates. When 
furnished with that information, graduates, especially purists, may be more orientated to the sector as a source of employment - as the ASA framework would suggest. These findings are drawn from seven case studies of social care voluntary organizations in Scotland. Although caution should always be exercised in extrapolating from one country, and so from the specific to the general, the findings do resonate with other studies, for example, ATA Management (2006) and Zebra Square (2006). The findings do, therefore, appear to have some wider applicability, at least for the United Kingdom more generally and wherever there is both a reconfigured voluntary sector and a need to employ more graduates.

The research findings' main contribution, however, lies in conceptualizing and providing empirical verification of the sector's graduate recruitment problems as a systems failure. Doing so enables practical solutions to be identified. Primarily, the voluntary sector needs to better present itself to graduates. This exercise should be two pronged. First, consideration should be given to changing the voluntary label in Scotland, which, unsurprisingly, conjures up images of a volunteer army of Miss Marples wearing woolly cardigans and knitting tea cosies. Frumkin (2002) has noted how "the process of arriving at a single term to designate this sphere of activity has been long and conflicted" (p. 11), creating a long-standing confusion over the most appropriate terminology to describe the sector. He listed 10 different terms that have been used over the years, with each having its own historical and political baggage. For example, he noted the common usage of charity sector, which may now be considered synonymous with Victorian England, class elitism, and aid for the poor. Similarly, the term third sector, although having some currency currently among research, is viewed pejoratively among practitioners for suggesting that the voluntary sector is third in line after the private and public sectors. Ultimately, Frumkin settled on what he described as the "cumbersome though descriptively accurate" (p. 15) "non-profit and voluntary sector." However, whatever term is used for the sector, it has to dispel the myth of only volunteering and raise the profile of paid jobs, particularly among graduates. Second, short of introducing and mainstreaming nonprofit management education courses within Scottish universities (see Donnelly-Cox $\&$ McGee, 2007, for the Irish experience), there needs to be improved information about paid work and graduate career opportunities within the sector (whatever its appellation) and, most obviously, through university careers services. The pilot graduate placement scheme and graduate careers conference reported here provide examples of initiatives to rectify this problem, but more needs to be done. This better supply of information can help graduates determine the congruence between their own values and those of voluntary organizations and so facilitate attraction and continued tenure through the ASA framework. The intention would then be to attract purist graduates likely to possess an affective commitment to working in the sector. For other graduates, opportunities to use their skills and develop their employability, even if they do not remain in employment within the sector or concur with its values, can also be attractive and should be promoted by voluntary organizations as part of the better supply of information to prospective graduate recruits. 
There is clearly a supply of graduates who would be appropriate for employment in the voluntary sector and also a demand by voluntary organizations for these graduates. However, as the article has also noted, there are demand constraints centered on the funding of the sector. Current full-cost recovery is a misnomer. Voluntary organizations typically receive full-cost recovery for discrete service provision, covering the direct costs of projects rather than any extras, such as, for example, graduate-level expertise in marketing or IT, which although not front-line activities are now essential to the operation of voluntary organizations. The instability caused by project funding in the sector is exacerbated by the fact that voluntary sector organizations in Scotland, as in the rest of the United Kingdom, are often required to regularly reapply for short-term funding, commonly on an annual basis. Consequently, planning and resourcing decisions can be difficult (Labour Research, 2007a). Although many voluntary organizations would like to create permanent jobs suitable for graduates, financial barriers often exist. The frustration caused by these constraints was highlighted by Kidco's human resource director:

The most frustrating thing for me is that I am absolutely blessed to have such a great staff team and I cannot use them to the best advantage for the organization, just simply because there are not those resources. We could take on the world if we had the space.

Relatedly, pay is a long-standing problem that requires a long-term solution with government needing to rethink funding formulas if the continued transfer of services is to be efficacious. Government must work with social care voluntary organizations to deal with the pay issue through real full-cost recovery so that voluntary organizations can meet the actual costs of their service provision. However, although higher pay is desirable, the altruism payoff in which employees are willing to trade lower salaries against task significance means that the firstorder priority has to be attracting purist graduates. To do so requires the systems failure to be rectified through the provision of information about the opportunities and advantages of working in the sector to address the current skills shortages. Through exploratory research analyzing the social care subsector in Scotland, this article has affirmed these skills shortages and identified the reasons for systems failure. Based on these findings, it has also made inchoate suggestions about how this failure might be overcome.

\section{Acknowledgements}

The authors would like to thank Eli Dutton for project managing the initial research reported in this article and Shiona Chillas for her research assistance. 


\section{Note}

1. A British phrase applied to objects of ridicule or abuse.

\section{References}

ATA Management. (2006). Third Sector, first choice: Exploring the viability of a new scheme to attract graduates to the voluntary and community sector as the first stage in building their career. NCVO. Retrieved October 25, 2007, from http://www.ukworkforcehub.org.uk/ DisplayPage.asp?pageid=9982\#HR[

Barnard, J., Broach, S., \& Wakefield, V. (2004). Social care: The growing crisis. London: Social Care Employers Consortium.

Bates, P., Tyers, C., Connor, H., \& Loukas, G. (2006). The labour market for graduates in Scotland. Glasgow, UK: Futureskills Scotland, Scottish Enterprise.

Bates, P., \& Tyers, C. (2006). Destinations of Scottish graduates, higher education careers services unit. Retrieved October 25, 2007, from http://www.prospects.ac.uk/cms/ShowPage/ p!edcFXXF\#Destinations \%20of\%20Leavers\%20from $\% 20$ Higher $\% 20$ Education $\% 20$ survey

Brindle, D. (2008, February 20). All together now for community cohesion. Guardian, p. 2.

Brown, P., \& Hesketh, A. (2004). The mismanagement of talent. Oxford, UK: Oxford University Press.

Cunningham, I. (2005). Sweet charity! Managing employee commitment in the UK voluntary sector. Employee Relations, 23, 226-239.

Dart, R. (2004). Being "business like" in nonprofit organisation: A grounded and inductive typology. Nonprofit and Voluntary Sector Quarterly, 33, 290-310.

Donnelly-Cox, G., \& McGee, S. (2007). Institutionalizing support for nonprofit management education: Developing a case for state investment. Nonprofit and Voluntary Sector Quarterly, 36, 136S-147S.

Elias, P., \& Purcell, K. (2001). Scotland's graduates: Moving on. Glasgow, UK: University of Strathclyde/The Industrial Society.

Felstead, A., Gallie, D., Green, F., \& Zhou, Y. (2007). Skills at Work 1986-2006. Oxford, UK: Economic and Social Research Council.

Frumkin, P. (2002). On being non-profit: A conceptual and policy primer. Cambridge, MA: Harvard University Press.

Futureskills Scotland. (2005). Voluntary sector: Scottish Sector Profile 2005. Glasgow, UK: Author.

Herriot, P. (1989). Selection as a social process. In M. Smith \& I. Robertson (Eds.), Advances in selection and assessment. New York: John Wiley.

Higher Education Statistics Authority. (2008a). 2006/7 student data. Retrieved March 17, 2008, from http://www.hesa.ac.uk/index.php?option=com_content\&task=view\&id=1197 \&Itemid $=266$ 
Higher Education Statistics Authority. (2008b). HESA destinations of leavers from higher education institutions reveals reduction in rate of unemployment for recent graduates (HESA Press Release 126). Retrieved March 17, 2008, from http://www.hesa.ac.uk/index .php?option=com_content\&task=view\&id=1282\&Itemid=161

Keep, E., \& Mayhew, K. (1999). The assessment: Knowledge skills, and competitiveness. Oxford Review of Economic Policy, 18(1), 1-15.

Labour Research. (2007a, August). Voluntary sector faces bidding war, pp. 12-14.

Labour Research. (2007b, December). Voluntary sector expansion is "due to social care transfers, "p. 4.

Little, M. (2008, February 20). Unions find more losers than winners. Guardian, p. 5.

Mason, G. (2001). Mixed fortunes: Graduate utilisation in service industries. London: National Institute for Economic and Social Research.

Meyer, J. P., \& Allen, N. J. (1991). A three component conceptualization of organisational commitment. Human Resource Management Review, 1(1), 61-89.

Meyer, M. (2006). Wie viel Wirtschaft verträgt die Zivilgesellschaft? Über Möglichkeiten und Grenzen Wirtschaftlicher Rationalität in NPO. Tagung 'Bürgergesellschaft-Wunsch und Wirklichkeit. Berlin, Germany: Wissenschaftszentrum Berlin.

Munro, S., \& Shah, R. (2004). Voluntary sector: Scottish sector profile. Glasgow, UK: Futureskills Scotland/Scottish Council for Voluntary Organisations.

Murray, S. (2008, October 14). Passion and skills in aid of a good cause. Financial Times, p. 6.

Nickson, D., Warhurst, C., Dutton, E., \& Hurrell, S. A. (2008). A job to believe in: Recruitment in the Scottish voluntary sector. Human Resource Management Journal, 18(1), 18-33.

Parry, E., Kelliher, C., Mills, T., \& Tyson, S. (2005). Comparing HRM in the voluntary and public sectors. Personnel Review, 34, 588-602.

Parsons, E., \& Broadbridge, A. (2006). Job motivation and satisfaction: Unpacking the key factors for charity shop managers. Journal of Retailing and Consumer Services, 13(2), 121-131.

Perry, J. L., Brudney, J. L., Coursey, D., \& Littlepage, L. (2008). What drives morally committed citizens? A study of the antecedents of public service motivation. Public Administration Review, 68, 445-457.

Perryman, S. (2002). The IES annual graduate review 2002 update: Part 2 graduates early careers. Brighton, UK: Institute for Employment Studies.

Perryman, S. (2003). The IES annual graduate review 2003 update: Business as usual? Trends in student and graduate numbers. Brighton, UK: Institute for Employment Studies.

Schneider, B., Goldstein, H. W., \& Smith, D. B. (1995). The ASA framework: An update. Personnel Psychology, 48, 747-773.

Scottish Government. (2008). Attainment in higher education and destinations of leavers 2006-07. RetrievedMarch 17,2008, fromhttp://www.scotland.gov.uk/Publications/2008/10/27134546/19

Shah, R. (2004). Labour market information report. Edinburgh, UK: Scottish Council for Voluntary Organisations.

Tierney, T. J. (2006). The nonprofit sector's leadership deficit. The Bridgespan Group. Retrieved June 19, 2009, from http://www.bridgespangroup.org/PDF/LeadershipDeficit WhitePaper.pdf 
Wilding, K., Collis, B., Lacey, M., \& McCullough, G. (2003). Futureskills 2003-A skills foresight research report on the voluntary sector paid workforce. London: VSNTO.

Wilding, K., Collins, G., Jochum, V., \& Wainwright, S. (2004). The voluntary sector almanac, 2004. London: NCVO.

Wilson, M. I., \& Larson, R. S. (2002). Nonprofit management students: Who they are and why they enroll. Nonprofit and Voluntary Sector Quarterly, 31, 259-270.

Zebra Square. (2006). Young people's perceptions and attitudes of working in the "voluntary, community \& charity sector. " Retrieved October 25, 2007, from http://www.ukworkforcehub.org.uk/DisplayPage.asp?pageid=9982\#HR 